\title{
TECHNICAL AND TECHNOLOGICAL COMPETENCE AS FOUNDATION FOR DIGITAL TRANSFORMATION
}

\author{
TEHNIČKA I TEHNOLOŠKA KOMPETENTNOST \\ KAO TEMELJ DIGITALNE TRANSFORMACIJE
}

\author{
Izv. prof. dr. sc Krešimir Buntak
}

E-mail: kresimir.buntak@unin.hr

Matija Kovačić, mag. ing. traff.

E-mail: matkovacic@unin.hr

Ivana Martinčević, univ. spec. oec.

Sveučilište Sjever, Koprivnica, Hrvatska/Croatia

E-mail: ivana.martincevic@unin.hr

UDK/UDC: $331.101 .52+005.336 .2$

JEL klasifikacija/JEL classification: O33; L15

DOI: $10.30657 /$ hdmk.2020.08

Pregledni članak/Review

Jezik/Language: Hrvatski/Croatian

\begin{abstract}
:
Industry 4.0 is a term that first appeared in 2011 in the context of the German Development Strategy until 2020. The advent of Industry 4.0 brings with it several technical and technological innovations that affect organizational competitiveness. However, for an organization to implement such innovations in its business, it is necessary to carry out a digital transformation of the business. Digital transformation of the business as an imperative imposes a process approach in an organization since digital transformation consequently increases the complexity of the organizational system as well as the complexity of its management, and the process approach is imposed as the optimal way to manage in such an environment. However, the implementation of technical and technological innovations arising from the development of Industry 4.0 has, consequently, a growing challenge, as communication and information exchange between implemented systems takes place via the Internet, resulting in the risk of unauthorized entry into the communication channel and the risk of taking control of the systems. Furthermore, for an organization to be able to perform a digital transformation of its business at all, it is necessary to ensure technical and technological competence, which is one of the requirements that ISO 9001:2015 imposes on organizations.
\end{abstract}

Key words: digital transformation, organizational competence, process approach. 


\section{INTRODUCTION}

The development of Industry 4.0 and the requirement regarding the imperative of adapting to the new conditions in the environment consequently have the necessity of every organization to adapt to the new conditions. Adaptation to turbulent market conditions as one of the requirements also has a digital transformation of the organization. Digital transformation signifies the application of new technologies such as IoT (Internet of Things), RFID (Radiofrequency identification), Big Data, sensor applications, autonomous systems, 3D printers, etc. The application of such technologies has the effect of improving organizational performance. ${ }^{1}$ Organizations that have successfully existed in the market so far without implementing digital technologies, with the fourth industrial revolution, must implement digital technologies to remain competitive in the market. ${ }^{2}$ The necessity for digital business transformation and adoption of the digital organization model is also because stakeholders are significantly changing their demands on the organization due to the possibility of product personalization. ${ }^{3}$ For organizations to carry out digital transformation, it is necessary to ensure their competence, and above all technical and technological.

Technical competence is related to the means of work in the organization, which represents machines, devices, materials, etc. Technological competence, on the other hand, refers to the processes and processes used by the organization, i.e. the use of tools, machines, devices, etc. Technical and technological competencies are part of organizational competence and are related to the intellectual capital held by the organization. Industry 4.0, as a requirement on today's organizations, places an increase in their technical, as well as technological competence as the demands of the stakeholders grow. However, digital transformation not only captures changes related to technical and technological competence, but also affects organizational processes, services, connections inside and outside the organization as well as the business model the organization has. ${ }^{4}$ Furthermore, the different technical and technological competencies of organizations are the basis for defining a digital transformation strategy. Digital transformation strategies bring with them different levels of risk that can range from minimal to substantial risks, as well as different models of collaboration with other organizations. Some strategies may include mapping, i.e. adapting models of other organizations, or experimenting with the implementation of different technologies. ${ }^{5}$ The success of the digital transformation is determined by the technical, technological but also the competence of the human resource that will use the implemented technology. In view of this, it is necessary to emphasize the increase of the technical and technological competence of the organization as a basis for competitiveness and for the successful implementation of digital transformation.

\footnotetext{
${ }^{1}$ Gregory Vial, "Understanding digital transformation: A review and a research agenda", The Journal of Strategic Information Systems., 2019, pp 118-144.

${ }^{2}$ Simon Chanias, Michael D. Myers and Thomas Hess, "Digital transformation strategy making in pre-digital organizations: The case of a financial services provider", The Journal of Strategic Information Systems, 2019, pp 1733.

${ }^{3}$ Peter C. Verhoef, Thijs Broekhuizen, Yakov Bart, Abhi Bhattacharya, John Qi Dong, Nicolai Fabian and Michael Haenlein, „Digital transformation: A multidisciplinary reflection and research agenda”, Journal of Business Research 2019.

${ }^{4}$ Ines Mergel, Noella Edelmann and Nathalie Haug, „Defining digital transformation: Results from expert interviews”, Government Information Quarterly, 2019.

5 Željko Tekic, and Dmitry Koroteev, "From disruptively digital to proudly analog: A holistic typology of digital transformation strategies" Business Horizons, 2019, pp 683-693.
} 
The aim of this paper is to show the importance of competencies of today's organizations that seek to transform their business through the implementation of digital innovations, as well as to show the importance of developing technical and technological competence as a basis for greater efficiency of the digital transformation of today's organizations.

This paper seeks to demonstrate the need for today's organizations to undergo digital transformation to remain competitive in the marketplace as well as to develop a new competitive advantage. Furthermore, the paper seeks to show the difference between technical and technological competence and to show the importance of organizational competence for quality management of the organization. Good governance of an organization can affects stakeholder satisfaction as well as the quality of the finished product or service provided

\section{METODOLOGY}

This paper is based on secondary research aimed at identifying existing knowledge in the field of digital transformation, as well as a theoretical overview of the technical and technological competence as well as the competence of the organization. The literature references used in this paper have been published in relevant databases of scientific and professional journals. In the papers used, the authors provide an overview of recent advances in digital transformation strategies, theoretical review, and case studies that describe the need and importance of digital transformation, or the use of innovations generated through the development of Industry 4.0.

\section{INDUSTRY 4.0 AND DIGITAL TRANSFORMATION}

Industry 4.0 is a new stage of industrial development where through horizontal and vertical process integration, as well as product connectivity, organizations can achieve significantly better performance than organizations not using Industry 4.0 technology. ${ }^{6}$ Such changes result in the imperative of digitizing the processes that take place in organizations and changing the focus from mass production to the production of customized products according to customer requirements. Furthermore, Industry 4.0 also takes a completely different approach to organizing and controlling the product life cycle. ${ }^{7}$ The application of new technologies has the consequence of increasing the competency of organizational employees as the organization implements new technology in its system that is one of the conditions of competence. ${ }^{8}$

Speaking to the technology that is a consequence of the development of Industry 4.0, it is necessary to mention that the technological innovations and concepts shown in Table 1 occur. and devices on a network that communicates and exchanges information, RFID which means short-term memory that stores product information, artificial intelligence, automated robotic-based systems that perform the activities for which they are designed, big data that means a database

\footnotetext{
${ }^{6}$ Lucas Santos Dalenogare, Guliherme Brittes Benitez, Néstor Fabián Ayala and Alejandro Germán Frank, "The expected contribution of Industry 4.0 technologies for industrial performance," International Journal of Production Economics, 2018 pp 383-394.

${ }^{7}$ Saurabh Vaidya, Prashant Ambad and Santosh Bhosle, "Industry 4.0-a glimpse”, Procedia Manufacturing, 2018, pp 233-238.

${ }^{8}$ Felipe Baena, Alvaro Guarin, Julian Mora, Joel Sauza, and Sebastian Retat, "Learning factory: The path to industry 4.0," Procedia Manufacturing, 2017, pp 73-80.
} 
within which to collect data on measurements made on sensors mounted on urban infrastructure and superstructure, etc.

The combination of such technologies enables the creation of so-called a smart concept supplemented with artificial intelligence can operate a complex system based on the processes it manages and unfolds that it monitors using implemented sensors. Therefore, the key to adopting a smart concept is a process approach, that is, a digital transformation based on the transformation of a traditional system into a process-oriented system. Digital transformation, as such, involves the implementation and use of technologies arising from the development of Industry 4.0, which have been previously listed.

- Smart factory: the term Smart means a standalone system that can function based on the data it collects using sensors placed in the process. The term smart factory in professional and scientific literature is also called factory of things, a U-Factory (ubiquitous factory), intelligent factory of the future, and real-time factory etc. No matter what the term is, a smart factory involves the use of automated systems as well as communication between such systems to increase the flexibility and personalization of manufactured products. ${ }^{9}$

- Smart city: it implies a variety of smart technologies such as smart economy, smart mobility, smart environment, smart management, smart people, etc. Just like a smart factory, it involves the implementation of sensors as well as devices that monitor variables such as traffic congestion, the number of harmful substances in the air, number of available parking spaces, etc. Uses measured variables as a basis for decision making. ${ }^{10}$

- Smart product: they mean the ability to collect and process data and information or exchange it with other products of this type as well as customers or their users via an internet connection. ${ }^{11}$

- Smart building: it involves the implementation of different types of sensors by which the building is managed, which means the ability to automate the building management activities as well as personalized activities that are related to the needs of the customer or user of such building. ${ }^{12}$

- Smart transport: It involves the use of technologies such as sensors, IoT, RFID, etc. in vehicles and traffic systems to manage traffic systems more efficiently and effectively. This includes the use of autonomous vehicles, that is, the transition of vehicles that use fossil fuels to their vehicles using renewable energy sources. ${ }^{13}$

- Smart grid: It implies an electricity grid that can independently locate a problem in the grid as well as ensure efficient distribution of electricity from renewable sources to all users or customers of the same. One of the requirements for the creation of such a

\footnotetext{
${ }^{9}$ Agnieszka Radziwon, Arne Bilberg, Marcel Bogers and Erik Skov Madsen, "The smart factory: exploring adaptive and flexible manufacturing solutions", Procedia engineering, 2014, pp 1184-1190.

${ }^{10}$ Yang Lu, "Industry 4.0: A survey on technologies, applications and open research issues", Journal of industrial information integration, 2017, pp 1-10.

${ }^{11}$ Ana Valencia Cardona, Ruth Mugge, Jan P. L. Schoormans, \& Hendrik N. J. Schifferstein, "The design of smart product-service systems (PSSs): An exploration of design characteristics", International Journal of Design, 2015.

12 James M. Sinopoli, "Smart buildings systems for architects, owners and builders", Butterworth-Heinemann, 2009.

${ }^{13}$ Ghassan Abu-Lebdeh, "Smart Transport Systems: Planning and Designing Transport Systems to Support Public Health”, Journal of Transport \& Health, 2017.
} 
network is the creation of a new one and the renewal of the existing electricity distribution infrastructure. ${ }^{14}$

The implementation of the listed technologies significantly increases the complexity of the systems, which imperatively imposes the development of new technologies and concepts to manage such systems. However, all emerging technologies must be based on a process approach as the process approach as such is the foundation for managing complex systems.

Some of the ways to manage such complex systems are the CPS (Cyber-Physical System), which enables operator intervention according to the data collected by sensors implemented in the system. As such, CPS implies technology based on the link between the physical system and the virtual system, as well as the ability for the operator to monitor the performance of the physical system and changes that it makes to the virtual system are transmitted to the physical system. ${ }^{15}$ On the other hand, the digital twin's concept involves the mapping of a physical system to a virtual one to optimize the processes that take place in the system. ${ }^{16}$

\section{THE IMPORTANCE OF SYSTEMIC THINKING}

The systematic approach and systems thinking are the basis for the complete transformation of the system and its digital, that is, process orientation. System theory explains the relationships between system components and tells how all system components are interconnected. In other words, if the performance of one of the components of the system falls, this will result in a decline in the overall performance of the system. In addition, the organization's effort to ensure the maximum of individual systems components, as a result, will not result in the creation of a system maximum. In view of this, organizations are advised to provide optimum components to achieve the optimum in the overall organizational system. Otherwise, organizations will invest many resources which will result in system inefficiency as the rule of system theory described above applies. In other words, an organization's efforts to digitally transform one component (department, function) in an organization will not, consequently, improve and increase the performance of the organization.

\section{TECHNICAL AND TECHNOLOGICAL COMPETENCE}

Competence means the competence, scope, authority of an institution or person, that is, someone or something that is capable, knowledgeable, and proficient in an area. From an organizational perspective, competence can be referred to as the competence of the individual (employee) and the competence of the organization. The competence of the organization is related to the requirements of the environment of the organization related to the adaptation to the new requirements, i.e. new conditions in which the organization operates. In view of this, organizational competence is technical and technological competence. Furthermore, competence

\footnotetext{
${ }^{14}$ Ramazan Bayindir, Ilhami Colak, Gianluca Fulli and Kenan Demirtas, "Smart grid technologies and applications. Renewable and Sustainable Energy Reviews”, 2016, pp 499-516.

${ }^{15}$ Sebastian Thiede, Max Juraschek and Christoph Herrmann, "Implementing cyber-physical production systems in learning factories", Procedia Cirp, 2016 pp 7-12.

${ }^{16}$ Fei Tao, Quinglin W. Qi, Lihui Wang and A. Y. Nee, "Digital twins and cyber-physical systems toward smart manufacturing and Industry 4.0: Correlation and comparison”, Engineering, 2019, pp 653-661.
} 
as such becomes one of the fundamental characteristics of a well-managed organization with the organization's documentation and manageability. ${ }^{17}$ Technical competence refers to the existence of adequate technical systems, i.e. infrastructure, while technological competence is directed towards the existence of specific methods, i.e. procedures used by an organization in the processes that take place in its subsystems.

In addition, it is worth mentioning, since one of the components of an organization's competence and human resource competence is the mention of intellectual capital and its impact on increasing the organization's competence. Intellectual capital can be divided into:

- Human capital - which implies the knowledge and skills of employees;

- Structural capital - which means business processes that take place in the organization, routines, intellectual property, etc.,

- Consumer capital - which implies a relationship and relationship with consumers and suppliers of the organization. ${ }^{18}$

Competency is one of the requirements of the ISO 9001:2015 standard, which in clauses 7.1.2 and 7.1.3 speaks of the need to secure the infrastructure as well as employees who possess the knowledge and skills necessary for the normal conduct of business processes. Furthermore, in relation to the creation and management of intellectual capital, the norm in clause 7.1.6 speaks of the need for each organization to define the knowledge necessary to carry out all processes in the organization. In other words, an organization needs to ensure competency so that its processes can proceed in accordance with the requirements placed on the processes by stakeholders.

Speaking of digital transformation, digital transformation also implies adopting a process approach, which requires organizational competency. In addition, since digital transformation implies the implementation of new technologies, i.e. new machines and devices, for an organization to successfully carry out digital transformation, it is necessary to implement technological innovations such as IoT, sensors, RFID, automated systems based on artificial intelligence, etc. its competence which can directly correlate its competitiveness in the market.

Furthermore, with the implementation of new technology and new technical advancements, it is necessary to ensure the competence of the human resource that manages such systems, since one of the requirements of the standard is the need to provide competent employees whose competencies meet the requirements set in the process.

\section{DISCUSSION}

The inevitability of digital transformation stems from the increasing demands of stakeholders as well as the new industrial revolution. For organizations to transform their businesses into digital-oriented, it is necessary to adopt and implement new technical and technological innovations, which increases organizational competence. However, as the newly implemented technical and technological innovations arising from Industry 4.0 are based on Internet-based communication, there is a certain risk that third parties may be undesired from entering an established Internet connection between machines and devices. Organizations need to

\footnotetext{
${ }^{17}$ Krešimir Buntak, Zdenko Adelsberger, Ana Trajković i Dejan Adelsberger, „Utjecaj upravljanja intelektualnim kapitalom na organizacijsku kompetentnost“, 8 nacionalni skup "Sistem kvaliteta - uslov za uspešno poslovanje i konkurentnost", 2011.

${ }^{18}$ Ibid.
} 
develop ways to protect such an established connection from unwanted intrusions. For this purpose, the organization has at its disposal the ISO 27001 standard, or information security management system. In addition to the security management system, an organization can also establish a risk management system using ISO 31000, that is, a business continuity management system using ISO 22301. By establishing two or more management systems, an organization creates an integrated management system, which becomes imperative since the requirements that stakeholders place on the organization they are becoming larger and it is imperative to define how to satisfy them.

\section{CONCLUSION}

The paper shows the need of today's organizations, focused on the digital transformation of business and the adoption of a process approach. Current professional and scientific research addresses both digital transformation models and the benefits of digital transformation. However, the lack of scientific and professional work indicates the need to adopt a process approach as a basis for implementing the digital transformation of an organizational system.

Compared to other studies, this secondary research was directed towards demonstrating technical and technological competence as a basis for conducting digital transformation. Technical and technological competence can also determine the competitiveness of an organization in the market, but they are also a requirement, ie one of the determinants of a well-managed organization. Furthermore, technical and technological competence are two components of organizational competence, with human potential as the third component. Observing digital transformation through the sphere of competence is at the same time the fundamental difference between this paper and other professional and scientific papers.

The practical purpose of this research is to indicate the organizational need to create an integrated management system as well as to develop the competence of the organization, which can affect the competitiveness of the organization in the market.

The limitation of this research is related to the type of research since it is based on the knowledge already gathered from other professional and scientific papers. In view of this, future researchers in the field are advised to conduct primary research aimed at identifying the success of digital transformation with respect to the degree of maturity of technical and technological competence, as well as identifying a correlation between organizational competence and market competitiveness.

\section{Sažetak:}

\section{TEHNIČKA I TEHNOLOŠKA KOMPETENTNOST KAO TEMELJ DIGITALNE TRANSFORMACIJE}

Industrija 4.0 pojam je koji se prvi puta pojavljuje 2011. godine u kontekstu Njemačke razvojne strategije do 2020. godine. Pojava Industrije 4.0 sa sobom donosi niz tehničkih i tehnoloških inovacija koje utječu na organizacijsku konkurentnost. Međutim, kako bi organizacija takve inovacije mogla implementirati u svoje poslovanje, neophodno je provesti digitalnu transformaciju poslovanja. Digitalna transformacija poslovanja kao imperativ nameće procesni pristup u organizaciji budući da digitalna transformacija kao posljedicu ima povećanje složenosti organizacijskog sustava kao i složenost njegovog upravljanja, a procesni pristup se nameće kao optimalan način za upravljanje u takvom okruženju. No, implementacija 
tehničkih i tehnoloških inovacija koje proizlaze iz razvoja Industrije 4.0 kao posljedicu ima sve veće izazove budući da se komunikacija i razmjena informacija između implementiranih sustava odvija posredstvom interneta iz čega proizlazi rizik od neovlaštenog ulaza u komunikacijski kanal i rizika od preuzimanja kontrole nad sustavima. Nadalje, kako bi organizacija uopće mogla provesti digitalnu transformaciju poslovanja, neophodno je osigurati tehničku i tehnološku kompetentnost što je jedan od zahtjeva koji norma ISO 9001:2015 postavlja na organizacije.

Ključne riječi: digitalna transformacija, organizacijska kompetentnost, procesni pristup.

\section{LITERATURE}

1. Abu-Lebdeh, G., "Smart Transport Systems: Planning and Designing Transport Systems to Support Public Health", Journal of Transport \& Health, 2017.

2. Baena, F., Guarin, A., Mora, J., Sauza, J. and S. Retat, "Learning factory: The path to industry 4.0”, Procedia Manufacturing, 2017.

3. Bayindir, R., Colak, I., Fulli, G. and K. Demirtas, "Smart grid technologies and applications", Renewable and Sustainable Energy Reviews, 2016.

4. Buntak, K., Adelsberger, Z., Trajković, Ana and D. Adelsberger, „Utjecaj upravljanja intelektualnim kapitalom na organizacijsku kompetentnost", 8 nacionalni skup "Sistem kvaliteta - uslov za uspešno poslovanje i konkurentnost", Asocijacija za kvalitet i standardizaciju Srbije, 2011.

5. Chanias, S., Myers, M. D. and T. Hess, "Digital transformation strategy making in pre-digital organizations: The case of a financial services provider", The Journal of Strategic Information Systems, 2019.

6. Dalenogare, L. S., Benitez, G. B., Ayala, N. F. and A. G. Frank, "The expected contribution of Industry 4.0 technologies for industrial performance", International Journal of Production Economics, 2018.

7. ISO 9001:2015 Quality management system - requirements, ISO organization, 2015.

8. Lu, Y., "Industry 4.0: A survey on technologies, applications and open research issues, "Journal of industrial information integration", 2017.

9. Mergel, Iness, Edelmann, Noella and Nathalie Haug, ,Defining digital transformation: Results from expert interviews", Government Information Quarterly, 2019.

10. Radziwon, Agnieszka, Bilberg, A., Bogers, M. and E. S. Madsen, "The smart factory: exploring adaptive and flexible manufacturing solutions", Procedia engineering, 2014.

11. Sinopoli, J. M., "Smart buildings systems for architects, owners and builders", ButterworthHeinemann, 2009.

12. Tao, F., Qi, Q. W. and A. Y. Nee, "Digital twins and cyber-physical systems toward smart manufacturing and Industry 4.0: Correlation and comparison. Engineering", 2019.

13. Tekic, Z. and D. Koroteev, "From disruptively digital to proudly analog: A holistic typology of digital transformation strategies", Business Horizons, 2019.

14. Thiede, S., Juraschek, M. and C. Herrmann, ,Implementing cyber-physical production systems in learning factories", Procedia Cirp, 2016.

15. Vaidya, S., Ambad, P. and S. Bhosle, "Industry 4.0-a glimpse," Procedia Manufacturing, 2018. 
16. Valencia Cardona, M. Ana, Ruth Mugge, Schoormans, J. P. and H. N. Schifferstein, "The design of smart product-service systems (PSSs): An exploration of design characteristics", International Journal of Design, 2015.

17. Verhoef, P. C., Broekhuizen, T., Bart, Y., Bhattacharya, A., Dong, J. Q. and M. Haenlein, „Digital transformation: A multidisciplinary reflection and research agenda”, Journal of Business Research, 2019.

18. Vial, G., "Understanding digital transformation: A review and a research agenda", The Journal of Strategic Information Systems, 2019. 